\title{
A STUDY TO COMPARE VARIOUS ASPECTS OF MEMBERS OF JOINT AND NUCLEAR FAMILY
}

\author{
S.B. Bansal ${ }^{1}$, Sanjay Dixit ${ }^{2}$, Geeta Shivram³ ${ }^{3}$, Dhruvendra Pandey ${ }^{4}$, Satish Saroshe ${ }^{5}$
}

\section{HOW TO CITE THIS ARTICLE:}

S.B. Bansal, Sanjay Dixit, Geeta Shivram, Dhruvendra Pandey, Satish Saroshe. "A Study to compare various aspects of members of Joint and Nuclear Family". Journal of Evolution of Medical and Dental Sciences 2014; Vol. 3, Issue 03, January 20; Page: 641-648, D0I:10.14260/jemds/2014/1879

BACKGROUND: Family is where our roots take hold and from there we grow. In India, the joint family system has been in existence since ancient times. However, with the passage of time, the joint family system has disintegrated, giving rise to the nuclear family system. AIMS \& OBJECTIVE: To Study socio demographic pattern of different types of family of Indian society, to know the attitude of members of different family type towards their family composition and to know whether current family pattern has any effect on their health status. SETTINGS AND DESIGN: A cross sectional study was conducted in urban area of Indore district. MATERIAL \& METHOD: A cross sectional study with written informed consent was conducted in 100 families (50 joint families and 50 nuclear families) an urban area of Indore city. Families were selected using sequential sampling method. All the married members of family were included in study. A predesigned semi structured questionnaire was used to interview the respondent members of family at the time of visit. The questions included demographic profile, satisfaction with current family pattern, opinions about changing trends of family system and overall health status of members of family. Statistical Analysis: The data was analyzed using Microsoft office excel and SPSS version 20. Chi square Test and Mann Whitney U Test were applied. RESULTS: In the nuclear families 35 males and 30 female members and in joint families 126 males and 110 females participated in the study. 68\% male and 50\% females in nuclear families and $18 \%$ males and $67 \%$ females in joint families were heavily loaded with work responsibility. In Nuclear family 38\% males and $42 \%$ females had poor health status. $47 \%$ and $39 \%$ males of nuclear families had alcohol and smoking habits respectively. $96 \%$ of females of nuclear families had awareness of Antenatal care. CONCLUSION: The overall health status of members of nuclear families was poor as compared to members of joint families. Awareness about health care facilities is more in nuclear families.

KEY WORDS: Nuclear Family, Joint Family, Health status, Antenatal Care.

INTRODUCTION: The family is the first essential cell of human society. - Pope John XXIII.

The family has been and continues to be one of the most important elements in the fabric of Indian society. The bond that ties the individual to his family, the range of the influence and authority that the family exercises make the family in India not merely an institutional structure of our society, but accord give it a deep value. ${ }^{1}$

Family types are classified differently by various scholars. Kapadia et. al $^{2}$ have identified two broad family types namely; nuclear and joint/extended, while Richard et $\mathrm{al}^{4}$ and Caldwell et al ${ }^{3}$ have classified into nuclear, stem, joint, joint-stem and others.

A nuclear family can be defined as a household consisting of two married, heterosexual parents and their legal children (siblings). Joint family can be defined as members of a uni-lineal descent group (a group in which descent through either the female or the male line is emphasized) 
live together with their spouses and offspring in one homestead and under the authority of one of the members. ${ }^{1}$

In India, the joint family system has been in existence since ancient times. However, with the passage of time, the joint family system has disintegrated, giving rise to the nuclear family system. 5 Job opportunities available in the cities become the main cause of the disintegration of the joint family system. There is a lack of living space in the cities. It is difficult to accommodate all the members of a joint family in a single house in the city. Also cost of living is very high in the cities. ${ }^{5}$

The main advantage of the nuclear family is that a couple has complete privacy. Another advantages of nuclear family includes specific sense of freedom that gives a nuclear family the ability to live life as they wish, it keeps the family away from other nuclear families first, which avoid stress in discomfort and they are usually well maintained economical families. The disadvantages of nuclear families includes the father and mother, if both is going to work then in that case they have to leave their child alone/ to be baby-sited, where the child grows away from their family values, feeling of safety and security is lacking and also not much of a support system. 6

The advantages of joint family includes family members never be alone, you have persons to look after your kids, Works can be shared, Expenses can be shared, Guidance will be there, Caring will be there. Disadvantages includes family members may lose individuality, Interference in all the activities, and lack of privacy for their personal feelings. ${ }^{7}$

Although it can be argued that over the years joint family is slowly giving way to nuclear families, a number of studies reveal that despite the fact of living in the nuclear family set-up many functional relationships are maintained with the nonresidential family members (Kapadia et. al2; Agarwala et. al8; Desai et. al ${ }^{9}$ : Gore et. al $^{10}$ ). As still in India most of the marriages are arranged by the parents, marital life begins in the parents' family and later depending on the situation, a dwelling unit is arranged by the parents or other older members of the family (Richard et al. ${ }^{4}$ ). Hence, it is possible that the decisions taken by the members of the nuclear family are guided by their parents and relatives.

The nuclear family, same as elsewhere, is now the characteristic feature of the Indian society. According to the Census of India (2011) data, of all the households' nuclear family constituted 70 percent and single member or more than one member households without spouse comprised about 11 percent. The extended and joint family or households together claim merely 20 percent of all households. This is the overall picture about the entire country, whereas in the case of urban areas the proportion of nuclear family is somewhat higher still.11

Family health is more than the sum of the personal health of individuals (including father) who form the family since it also takes in to consideration-interaction in terms of health (physical and psychological) between members of the family-relationships between the family and its social environment-at all stages of family life in its different structural types".12

In a joint family, the child gets many adult figures for his or her identification. In these families, children are overprotected and sheltered and, as a result, self-non- self-segregation is hampered. In a nuclear family, the child has a limited set of adult models to emulate. As a result, he or she develops a strong sense of personal bond with the parents, with a greater scope of developing clear-cut self-identity (Sinha, 1984). ${ }^{13}$

This study tried to compare the socio demographic pattern of different types of family of Indian society specially Nuclear and Joint Family type. The present study was carried out with the 
aim of assessing socio demography, attitude of family members toward their family composition and their health status.

MATERIAL\& METHOD: A cross sectional study was conducted in urban area of Indore district, area being selected using simple random sampling. The families included in study were selected using sequential sampling method. Study population included only those family members who were present at the time of IPI (Interpersonal interview). Written informed consent was obtained prior to interview. The process was carried out for 4 months till the sample size of 100 families was fulfilled (50 joint families and 50 nuclear families). Inclusion Criteria included all the married members of family who gave informed consent. Exclusion Criteria included members who not gave consent or not respond well. The Pretested Semi structured questionnaire, included demographic profile, life style related factors, satisfaction with current family pattern, opinions about changing trends of family system and overall health status of members of family, domestic violence, parent child relationship, was used for data collection. The data was analyzed using appropriate statistical software (MS excel and SPSS version 20). P value less than 0.05 would consider statistically significant.

RESULTS: In the 50 nuclear families 35 males and 30 female members and in 50 joint families 126 males and 110 females were participated in the study. Most common age was between 26 - 40 years with education more than higher Secondary. Selected families were mainly belonging to Upper middle class, middle class, and lower middle class (A/c Modified Kuppuswami classification).

Among males of nuclear families $25.71 \%$ were moderately work loaded, $68.57 \%$ heavily work loaded, $37.15 \%$ had poor health status, $48.57 \%$ alcohol addicted, $37.14 \%$ smokers, $28.57 \%$ had satisfactory freedom, $34.29 \%$ had satisfactory parent child relationship, $45.71 \%$ preferred joint family as their choice of living. Among males of joint families $65.87 \%$ were moderately work loaded, $18.25 \%$ heavily work loaded, $92.06 \%$ had more than average health status, $15.87 \%$ and $19.05 \%$ addicted to alcohol and smoking, $91.27 \%$ had satisfactory parent child relationship, $31.75 \%$ had satisfactory freedom, $57.94 \%$ preferred nuclear family as their primary choice.

Among females of nuclear families $50 \%$ heavily work loaded, $40 \%$ had poor health, 60\% had satisfactory parent child relationship, $26.67 \%$ had satisfactory freedom and $33.33 \%$ preferred joint family type. Among females of joint families $67.27 \%$ were heavy work loaded, $34.55 \%$ had good health status, $72.73 \%$ had satisfactory parent child relationship, $28.18 \%$ had satisfactory freedom, and $60.91 \%$ preferred nuclear family type.

Ante natal care (ANC) awareness was more in females of nuclear families $(96.67 \%)$ in comparison to females of joint families (63.63\%). 35.45\% females of joint families had home deliveries. 21(19.09\%) females of joint family had experienced domestic violence while only 1 $(3.33 \%)$ female in nuclear families.

DISCUSSION: The males in the nuclear family have to do heavier work than the males of joint family as in the joint family the work gets distributed. The females of the joint family are more work loaded than the females of the nuclear family because with the increase in number of family members the work increases consequently. 
As evident from the data, health status of the males and females both of the nuclear family is poor as compared to that of the males and females of the joint family. Dr. Haider ${ }^{14}$ showed in his study that joint family system is a causative factor in depression but is not the only factor responsible for development of depressive illness. Due to freedom that is available to the males of the nuclear family, alcohol habits are more prevalent as compared to joint families in which elder' $s$ puts restrictions.

There is only marginal difference the amount of freedom enjoyed by males of the two kinds of the families under study. It is misbelieve that the females of the joint families have lesser freedom than those of the females of the nuclear family. In fact, there is only a marginal difference in the amount of freedom perceived by the females of the either kind of the families.

The amount of antenatal awareness is clearly much higher in nuclear families than the joint families. Probably, the reasons behind this are the customs, belief and misbelieves which are more prevalent in joint families. The percentage of institutional deliveries is much higher in nuclear families than the joint families. In study of Fatmi $\mathrm{Z}$ et al, 31.6\% females of nuclear families received antenatal care in comparison of $27.4 \%$ females of joint families. ${ }^{15}$

Because of the increased work load, the fathers of the nuclear family could not give sufficient care to their children; hence the parent child relationship suffers. Whereas, in the Joint families there was distribution of the work so that the fathers can give sufficient time to their children and because of the increased responsibilities, the mothers of the nuclear could not give sufficient time to their children. Similar results were concluded in the study of Lena et al, 16 Norburg et al, ${ }^{17}$ Khatoon A et al. ${ }^{18}$, Sunawat R. et al. ${ }^{19}$ ) A study of Shukla et al reveals that women workers expressed that they had unsatisfactory relationship with their husbands (72\%), children (72\%), and in- laws (22\%). ${ }^{20}$

In our study $60 \%$ members of Nuclear families and $59 \%$ members of Joint families were in favor of nuclear family as their choice. Females of both the types of families preferred nuclear family type more as compared to males of both families. Same result was found in a study by Chitra Nair et al which concluded that almost $72 \%$ of Pune women prefer to live in a nuclear family, as opposed to just $50 \%$ men who favors the idea. ${ }^{21}$

In our study $19.09 \%$ females of joint families experience domestic violence in comparison to $3.33 \%$ females of nuclear families. Overall 95\% domestic violence was experienced in joint families. In the study of Dixit S et al 60\% domestic violence experienced in joint families and $40 \%$ in Nuclear families. ${ }^{22}$ According to Gandhi et al, factors related to poverty and lack of education among women make them more vulnerable to violence. ${ }^{23}$ while in study of Narang $\mathrm{H}$ et al no correlation was found in type of family and prevalence of domestic violence. ${ }^{24}$

This study was carried out with 50 nuclear families (65 members) and 50 Joint families (236 members) which was not sufficient to corroborate the finding of large picture and also all the members of the families were not available at the same time, needs more sample size to be incorporated which unfortunately was not included due to time constraint. Following recommendations are suggested based on the present study: (a) A good and loving relationship among family members, proper division of household chores would help improve quality of life in people living in joint families. (b) Members of joint families should promote institutional deliveries besides their previous experience and knowledge. (c) Giving quality time to one's child is important for their proper growth and development. Hence all families should give the required time to their 
children. (d) Special awareness and counseling session should be organized against domestic violence among females of joint families.

CONCLUSION: The overall health status of members of nuclear families was poor as compared to members of joint families. Males of nuclear families and females of joint families had heavily work loaded. Freedom in family members, parent child relation, Domestic violence were less and Awareness of Maternal Care, Life style related Factors (Alcohol and Smoking), freedom of Child were more in nuclear families.

\section{REFERENCES:}

1. Available from URL www.egyankosh.ac.in/bitstream/123456789/36906/1/Unit-1.pdf (access on 10 July)

2. Kapadia K. M. 1969. Marriage and Family in India. Oxford University, Press, Bombay.

3. Caldwell J. C., Reddy P. H. and Caldwell Pat., 1988. The Causes of Demographic Change: Experimental Research in South India. University of Wisconsin Press, Madison.

4. Richard J. et al. Family type and the aged. The Journal of Family Welfare, 1985; 31 (4): 31-38.

5. Dinayak Shenoy: A comparative essay on joint family vs. nuclear family system. 2008Dec 10th; access from http://www.rajputbrotherhood.com/knowledge-hub/essay/an-comparativeessay-on-joint-family-vs-nuclear-family-system.html

6. Asker. Advantages and disadvantages of nuclear family; access from: http://au.answers.yahoo.com/question/index?qid=20070917232612AAtZ3Lb (access on 10 July)

7. Agony A. What are advantages and disadvantages of joint family? Available from: http://wiki.answers.com/Q/What_are_advantages_and_disadvantages_of_joint_family

8. Agarwala B. R., 1962, Nature and extent of social change in a mobile commercial community. Sociological Bulletin.

9. Desai L. P., 1964. Some Aspects of Family in Mahuva. Asia Publishing House, Bombay.

10. Gore M., 1968. Urbanization and Family Change. Popular Prakashan, Bombay.

11. Census of India 2011

12. Abebe Gebremariam 2004 Family Health For Health Extension Workers, Jimma University Ethiopia Public Health Training Initiative, Page No. 4

13. Sinha D. (1984). Some recent changes in the Indian family and their implications for socialization. Indian Journal of Social Work, 45, 271-285.

14. Dr. Kamal Haider. Evaluation of the joint family system as a major cause of depression among married women of Sindh. Interdisciplinary Journal Of Contemporary Research In Business February 2013 vol 4, no 10.

15. Z. Fatmi, B. I. Avan Demographic, Socio-economic and Environmental Determinants of Utilisation of Antenatal Care in a Rural setting of Sindh, Pakistan Journal of Pakistan medical association, April 2002.

16. Lena E, Aminur R. Household Structure and Child Outcomes: Nuclear vs. Extended Families Evidence from Bangladesh. Columbia University. 2004 Apr 15. 
17. Norberg S, Magdalena. The phase out of the nuclear family: empirical studies on the economics and structure of modern Swedish families. Available from: http://ideas.repec.org/p/hhs/umnees/0708.html

18. Asia Khatoon, Miskeen Mohammad. The impact of nuclear and joint family system on the academic achievement of secondary school students in Karachi. Pakistan research repository. 2007

19. Reeta Sonawat. Understanding Families in India: A Reflection of Societal Changes Psicologia: Teoria e Pesquisa Mai-Ago 2001, Vol. 17 n. 2, pp. 177-186

20. Shukla A. (1988). Marital role behaviors and marital relationship among single and dual career families. Indian Journal of Clinical Psychology, 15, 84-88.

21. Chitra Nair. 72\% city women prefer nuclear families. TNN 2009 Nov 5; available from: http://mynation-foundation.688736.n2.nabble.com/72-city-women-prefer-nuclear-familiestd3957367.html.

22. Dixit S, Puranik AK, Saroshe S, Gupta G, Sirohi S, Rohit B. A study of the nature and causes of domestic violence among the attendees of a domestic violence counseling center of a tertiary level hospital of a city of Central India. Int J Med Sci Public Health 2013; 2:728-732.

23. Gandhi A. (1997). Violence against women, with reference to 498 A and 304 B, Indian Penal Code. Indian Journal of Social Work, 58, 582-597.

24. Harkiran Narang, Seema Singhal. Men as partners in maternal health: an analysis of male awareness and attitude. Int J Reprod Contracept Obstet Gynecol. 2013 Sep; 2(3):388-392.

\begin{tabular}{|c|c|c|c|c|c|c|}
\hline \multirow[t]{2}{*}{$\begin{array}{c}\text { Work load } \\
\text { Assessment }\end{array}$} & $\begin{array}{l}\text { Males of } \\
\text { Nuclear } \\
\text { family }\end{array}$ & $\begin{array}{c}\text { Males of } \\
\text { joint family }\end{array}$ & \multirow[t]{2}{*}{$P$ value } & $\begin{array}{c}\text { Females of } \\
\text { Nuclear Family }\end{array}$ & $\begin{array}{l}\text { Females of } \\
\text { joint family }\end{array}$ & \multirow[t]{2}{*}{$\begin{array}{c}\mathrm{P} \\
\text { value }\end{array}$} \\
\hline & No. (\%) & No. $(\%)$ & & No. $(\%)$ & No. (\%) & \\
\hline Mild & $2(5.72)$ & 20 (15.87) & \multirow{3}{*}{$<0.001^{*}$} & $3(10)$ & $16(14.55)$ & \multirow{3}{*}{$0.041^{*}$} \\
\hline Moderate & $9(25.71)$ & 83 (65.87) & & $12(40)$ & $20(18.18)$ & \\
\hline Heavy & $24(68.57)$ & $23(18.25)$ & & $15(50)$ & $74(67.27)$ & \\
\hline
\end{tabular}

Table 1: Comparison of Work related factors among Nuclear and Joint Families

* Chi square test applied, $\mathrm{p}<0.05$ consider significant

\begin{tabular}{|c|c|c|c|c|c|c|}
\hline \multirow{2}{*}{$\begin{array}{l}\text { Health } \\
\text { Status }\end{array}$} & $\begin{array}{c}\text { Males of } \\
\text { Nuclear family }\end{array}$ & $\begin{array}{c}\text { Males of joint } \\
\text { family }\end{array}$ & \multirow[t]{2}{*}{$P$ value } & $\begin{array}{c}\text { Females of } \\
\text { Nuclear Family }\end{array}$ & $\begin{array}{l}\text { Females of } \\
\text { joint family }\end{array}$ & \multirow{2}{*}{$\begin{array}{c}\mathrm{P} \\
\text { value }\end{array}$} \\
\hline & No. (\%) & No. (\%) & & No. (\%) & No. (\%) & \\
\hline Poor & $13(37.15)$ & $10(07.94)$ & \multirow{3}{*}{$<0.001^{*}$} & $12(40)$ & $18(16.36)$ & \multirow{3}{*}{$0.008^{*}$} \\
\hline Average & $5(14.28)$ & $53(42.06)$ & & 7 (23.33) & $54(49.09)$ & \\
\hline Good & $17(48.57)$ & $63(50)$ & & $11(36.67)$ & $38(34.55)$ & \\
\hline
\end{tabular}

Table 2: Comparison of health related factors among Nuclear and Joint Families

*Mann Whitney U test applied, $\mathrm{p}<0.05$ considered significant 


\section{ORIGINAL ARTICLE}

\begin{tabular}{|c|c|c|c|}
\hline Parameter & Females of Nuclear Family & Females of joint family & \multirow{2}{*}{ P value } \\
\hline ANC Awareness & No. (\%) & No. (\%) & \\
\hline Present & $29(96.67)$ & $70(63.63)$ & $<0.001^{*}$ \\
\hline Absent & $1(3.33)$ & $40(36.37)$ & \\
\hline Type of Delivery & & & \\
\hline Institutional Delivery & $28(93.33)$ & $71(64.55)$ & $0.002^{*}$ \\
\hline Home Delivery & $2(6.67)$ & $39(35.45)$ & \\
\hline Domestic Violence & & & $0.036^{*}$ \\
\hline Present & $1(03.33)$ & $21(19.09)$ & \\
\hline Absent & $29(96.67)$ & $89(80.91)$ & \\
\hline
\end{tabular}

Table 3: Comparison of health related factors among females of Nuclear and Joint Families

${ }^{*}$ Chi square test applied, $\mathrm{p}<0.05$ considered significant

\begin{tabular}{|c|c|c|c|}
\hline & Males of Nuclear family & Males of joint family & \\
\hline & No. (\%) & No. (\%) & P value \\
\hline Alcohol Habits & & & \\
\hline Present & $17(48.57)$ & $20(15.87)$ & $<0.001^{*}$ \\
\hline Absent & $18(51.43)$ & $106(84.13)$ & \\
\hline Smoking Habits & & & \\
\hline Present & $13(37.14)$ & $24(19.05)$ & $0.024^{*}$ \\
\hline Absent & $22(62.86)$ & $102(80.95)$ & \\
\hline
\end{tabular}

Table 4: Comparison of Life style related factors among Nuclear and Joint Families

*Chi square test applied, $\mathrm{p}<0.05$ considered significant

\begin{tabular}{|c|c|c|c|c|}
\hline & $\begin{array}{c}\text { Males of Nuclear } \\
\text { family }\end{array}$ & $\begin{array}{c}\text { Males of joint } \\
\text { family }\end{array}$ & $\begin{array}{c}\text { Females of Nuclear } \\
\text { Family }\end{array}$ & $\begin{array}{c}\text { Females of joint } \\
\text { family }\end{array}$ \\
\hline $\begin{array}{c}\text { Po. (\%) } \\
\text { relationship }\end{array}$ & No. (\%) & No. (\%) & No. (\%) \\
\hline Satisfactory & $23(65.71)$ & $115(91.27)$ & $18(60)$ & $80(72.73)$ \\
\hline Non-satisfactory & $12(34.29)$ & $11(08.73)$ & $12(40)$ & $30(27.27)$ \\
\hline Freedom & & & & $31(28.18)$ \\
\hline Satisfactory & $10(28.57)$ & $40(31.75)$ & $8(26.67)$ & $79(71.82)$ \\
\hline Non-satisfactory & $15(71.43)$ & $86(68.25)$ & $22(73.33)$ & \\
\hline $\begin{array}{c}\text { Type of family } \\
\text { Preferred }\end{array}$ & & & & $43(39.09)$ \\
\hline Joint Family Type & $16(45.71)$ & $53(42.06)$ & $10(33.33)$ & $67(60.91)$ \\
\hline Nuclear Family Type & $19(54.29)$ & $73(57.94)$ & $20(66.67)$ & \\
\hline \multicolumn{2}{|c|}{ Table 5: Comparison of Social factors among Nuclear and Joint Families } \\
\hline
\end{tabular}




\section{ORIGINAL ARTICLE}

\section{AUTHORS:}

1. S.B. Bansal

2. Sanjay Dixit

3. Geeta Shivram

4. Dhruvendra Pandey

5. Satish Saroshe

\section{PARTICULARS OF CONTRIBUTORS:}

1. Associate Professor, Department of Community Medicine, M.G.M. Medical College, Indore.

2. Professor and Head, Department of Community Medicine, M.G.M. Medical College, Indore.

3. Demonstrator, Department of Community Medicine, M.G.M. Medical College, Indore.
4. Resident, Department of Community Medicine, M.G.M. Medical College, Indore.

5. Assistant Professor, Department of Community Medicine, M.G.M. Medical College, Indore.

\section{NAME ADDRESS EMAIL ID OF THE CORRESPONDING AUTHOR:}

Dr. S.B. Bansal, 14, Sharma Enclave, Opposite Nandgaon, Tilak Nagar, Indore (Madhya Pradesh) - 452018.

Email-bansal_s_b@yahoo.com

Date of Submission: 28/12/2013.

Date of Peer Review: 29/12/2013.

Date of Acceptance: 03/01/2014.

Date of Publishing: 16/01/2014 